\title{
Informing designs for learning when shifting to digital
}

\author{
Stefan Hrastinski ${ }^{1}$
}

Accepted: 10 November 2020 / Published online: 17 November 2020

(c) The Author(s) 2020

\begin{abstract}
This paper is a response and considers practical and design implications of the article, The process of designing for learning: understanding university teachers' design work by Bennett et al. (Educ Technol Res Dev 65:125-145, 2017). Bennett et al. guide us in better understanding teachers' design practices and in discussions on how such practices could be improved. A key contribution of the article is presenting a descriptive model of the design process. As such, the article is focused on teachers' current design work, while giving more limited attention to how teachers' design practice could be improved. When looking forward, this response emphasizes that teachers should be encouraged to inform their designs for learning and iteratively improve their designs based on reflection and evaluation. If teachers take time to look into what is known and deliberately learn more along the way through reflection and evaluation, they will improve their understanding of how to design for learning.
\end{abstract}

Keywords Informed design · Design for learning $\cdot$ Shifting to digital $\cdot$ Reflection · Evaluation

There have been rather few studies on how teachers design for learning. One exception is the article The process of designing for learning: understanding university teachers' design work (Bennett et al. 2017). A key contribution of the article is uncovering important dimensions of teachers' design practices. The researchers developed a descriptive model of the design process based on interviews with 30 teachers from 16 Australian universities. Teachers followed a top-down approach in which they considered the learning outcomes, scope of content, ideas for activities and assessment strategy. Then, they specified the unit in detail, verifying against the more general ideas and adjusted if necessary. When teaching a unit, student feedback sometimes prompted the teacher to make changes of a more detailed nature. More than half of the teachers described that they identified future changes, typically after the unit was completed, but some also made notes during the unit. The design work extended before, while, and after a unit was taught, and emphasized the importance of reflection in teachers' design practice. A limitation of the article is that most

Stefan Hrastinski

stefanhr@kth.se

1 Division of Digital Learning, KTH Royal Institute of Technology, Osquars backe 31, 10044 Stockholm, Sweden 
interviewees were experienced teachers who were part of professional academic bodies, indicating that they were more experienced and engaged in teaching and learning. The article is focused on teachers' current design work, while giving more limited attention to how teachers' design practice could be improved.

This response suggests that the findings of the article could be understood and extended by considering design for learning as an informed practice. Teachers could be informed by 'what is known', such as theories, research, evidence, best and good practices, and previous experiences, by reflecting on how such knowledge could be applied in their teaching context (Oliver and Conole 2003). Being informed is also about applying professional judgment to reflect and act on analyses and evaluations of teaching and learning to improve student learning and the quality of teaching (Zwozdiak-Myers 2018). Thus, informing designs for learning could be based on what is known and by reflecting on and evaluating one's previous designs.

In the article by Bennett et al. (2017), a majority of the interviewees began by thinking about the learning outcomes or considering the content area when designing a new unit. Although it is encouraging that some teachers draw on learning outcomes when designing for learning, the designs would likely be of higher quality if teachers are also informed by what is known, such as research and best practices. In times where teachers must pivot to online learning with a short timeline, it might be tempting to conduct a 'quick' design (Hodges et al. 2020). However, an informed design is likely to be of higher quality as compared with a design solely based on a teacher's implicit assumptions about learning (Price and Kirkwood 2014).

An important contribution of the article by Bennett et al. (2017) is the conceptualization of teachers' design practices being extended before, while, and after a unit is taught, highlighting the dynamic nature of design and the importance of teacher reflection. The article found that more than half of the teachers reflected on how the unit could be improved for its next iteration. This is an implicit process where teachers get a sense of what 'worked' and what did not, which inform them when adjusting the unit as it is being taught and redesigning it the next time it is offered. Teachers could also be encouraged to evaluate their designs for learning with a focus on how these could be improved. For example, Hrastinski (in press-b) described how teachers conducted different types of evaluations, such as unit evaluations and questionnaires, verbal and written reflections from students, data from digital platforms, and assessment data, in order to understand how a design could be improved. When a teacher reflects on and evaluates a design for learning, there is not only potential to improve the design, but also to better understand how to design for learning in their specific context, which complements more general knowledge from, from example, research and best practices (Hrastinski, in press-a).

There are different 'teacher as researcher' approaches, such as Scholarship of teaching and learning (SOTL) (Hutchings and Shulman 1999) and Teaching as a design science (Laurillard 2012), which support teachers in gaining a deeper understanding of how to improve designs for learning. Having evidence to share with colleagues could be beneficial and support collegial learning on how to design for learning (Laurillard 2012). While 'teacher as researcher' approaches could certainly be useful, they have been adopted by a small part of the teacher population. All teachers design for learning, and we need to think about how the everyday design practices of teachers could be informed, which might be even more important in times when teachers need to rapidly shift to digital.

In conclusion, the article by Bennett et al. (2017) provides several important contributions. It guides us in better understanding teachers' design practices and in discussions on how such practices could be improved. Many of the interviewees were thinking about 
the learning outcomes, conducting adaptive changes responding to the current cohort, and reflecting on their experiences when re-designing a unit. In terms of future implications, this response emphasizes that teachers should be encouraged to inform their designs for learning and iteratively improve their designs based on reflection and evaluation. If teachers take time to look into what is known, and deliberately learn more along the way through reflection and evaluation, they will improve their understanding of how to design for learning.

Funding Open access funding provided by KTH Royal Institute of Technology.

\section{Compliance with ethical standards}

Conflict of interest The author declares that he has no conflict of interest.

Informed consent Informed consent was not required for this study.

Research involving human participants and/or animals This research submission does not involve human participants and/or animals.

Open Access This article is licensed under a Creative Commons Attribution 4.0 International License, which permits use, sharing, adaptation, distribution and reproduction in any medium or format, as long as you give appropriate credit to the original author(s) and the source, provide a link to the Creative Commons licence, and indicate if changes were made. The images or other third party material in this article are included in the article's Creative Commons licence, unless indicated otherwise in a credit line to the material. If material is not included in the article's Creative Commons licence and your intended use is not permitted by statutory regulation or exceeds the permitted use, you will need to obtain permission directly from the copyright holder. To view a copy of this licence, visit http://creativecommons.org/licenses/by/4.0/.

\section{References}

Bennett, S., Agostinho, S., \& Lockyer, L. (2017). The process of designing for learning: Understanding university teachers' design work. Educational Technology Research and Development, 65(1), 125145. https://doi.org/10.1007/s11423-016-9469-y.

Hodges, C., Moore, S., Lockee, B., Trust, T., \& Bond, A. (2020). The difference between emergency remote teaching and online learning. Educause Review. https://er.educause.edu/articles/2020/3/the-difference -between-emergency-remote-teaching-and-online-learning.

Hrastinski, S. (in press-a). Informed design for learning with digital technologies. Interactive Learning Environments. https://doi.org/10.1080/10494820.2020.1815221.

Hrastinski, S. (in press-b). Teachers as developers of local evidence to improve digital course design. Interactive Learning Environments. https://doi.org/10.1080/10494820.2019.1594959.

Hutchings, P., \& Shulman, L. S. (1999). The scholarship of teaching: New elaborations, new developments. Change: The Magazine of Higher Learning, 31(5), 10-15. https://doi.org/10.1080/000913899096042 18.

Laurillard, D. (2012). Teaching as a design science: Building pedagogical patterns for learning and technology. London: Routledge.

Oliver, M., \& Conole, G. (2003). Evidence-based practice and e-learning in Higher Education: Can we and should we? Research Papers in Education, 18(4), 385-397. https://doi.org/10.1080/026715203200017 6873.

Price, L., \& Kirkwood, A. (2014). Informed design of educational technology for teaching and learning? Towards an evidence-informed model of good practice. Technology, Pedagogy and Education, 23(3), 325-347. https://doi.org/10.1080/1475939X.2014.942749. 
Zwozdiak-Myers, P. (2018). The teacher's reflective practice handbook: Becoming an extended professional through capturing evidence-informed practice. London: Routledge.

Publisher's Note Springer Nature remains neutral with regard to jurisdictional claims in published maps and institutional affiliations.

Stefan Hrastinski is a Professor at the Division of Digital Learning and Director of Research Education at the Department of Learning in Engineering Sciences at KTH Royal Institute of Technology. He is also a Visiting Professor at Mid Sweden University. His research interests include online collaborative learning, just-in-time online tutoring, design and evaluation of emergent technologies for learning, and informed design for learning. 